\title{
Outlooks on Medicinal Properties of Eugenol and its Synthetic Derivatives
}

Ratnamala S Bendre*, Jamatsing D Rajput, Suresh D Bagul and Pravin S Karandikar

School of Chemical Sciences, North Maharashtra University, Jalgaon, Maharashtra, India

\begin{abstract}
Eugenol is found in essential oils of many plants. It belongs to a class of naturally occurring phenolic monoterpenoids, chemically it is an allyl chain-substituted guaiacol. Eugenol is a member of the phenylpropanoids class and is remarkably versatile molecule incorporated as a functional ingredient in several products and has found applications in the pharmaceutical, agricultural, fragrance, flavor, cosmetic and various other industries. Its vast range of pharmacological activities has been well-researched which include antimicrobial, anti-inflammatory, analgesic, antioxidant and anticancer activities. In present review we shortly summarize medicinal properties of Eugenol and its derivatives.
\end{abstract}

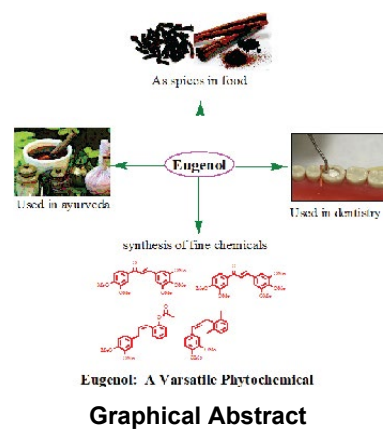

Keywords: Eugenol; Phenol; Anticancer; Dentistry; Biologically active derivatives

\section{Introduction}

Eugenol (4-allyl-1-hydroxy-2-methoxybenzene) is a well-known natural product occurring in many angiospermic plants with a pleasant scent and spicy taste [1]. Eugenol shows aromatic flavour, that's why it is called as aromatic phytochemical. Eugenol belongs to the group of phenylpropanes such as anethol, estragole and cinnamaldehyde, which is biosynthesized via the shikimate pathway. Eugenol is isolated from numerous aromatic plants [2-4] and used in perfumeries for spicy, clove-like and oriental-type fragrances. Eugenol is slightly soluble in water, a prerequisite for all medicinal uses $[5,6]$. It is used as a flavoring agent in the foods. Alike all phenols, eugenol is an antiseptic; used as disinfectant in mouthwash [7-9]. Due to its antiseptic and analgesic properties, it is used in dentistry; upon mixing with zinc oxide it forms cement for temporary fillings of the teeth [10-12]. Furthermore, eugenol and methyl eugenol are used as an insect attractant [13]. Together with other spice constituents, eugenol is under detailed investigation for its biological effects in the human body $[14,15]$.<smiles>C=CCc1ccc(O)c(OC)c1</smiles>

1. Eugenol

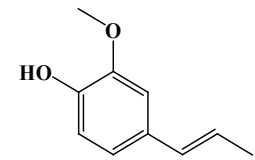

2. Isoeugenol

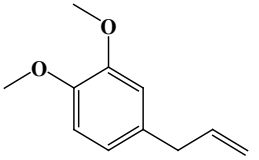

3. Methyl eugenol
Eugenol (1) isomer, namely isoeugenol (2) and methyl eugenol (3) also play vital role in devolvement of organic, medicinal, natural products, and carbohydrate chemistry. Isoeugenol (2) has been widely used as a key molecule for development of organic synthetic methodologies; similarly methyl eugenol (3) is used as a flavor in many food products, as a fragrance ingredient in perfumes, toiletries, and detergents, and as insect attractant in some pesticide formulations. As such Eugenol is commercially available in large quantities [16,17]; and the specific structure and ready availability of eugenol has turned this natural product into an interesting starting material, a useful building block for complex synthesis, as well as a valuable substrate for various biotransformations [18]. The current review will highlight the medicinal biography of eugenol and its derivatives.

\section{Occurrence of Eugenol}

Being a major component of clove; taste of clove is imparted by the chemical eugenol [19]. Eugenol is a compound found in certain plants, such as basil, cinnamon, lemon balm, and nutmeg, however, it is primarily extracted from clove plants. On extraction, it appears as a clear yellow liquid that smells strongly as clove, the concentration of eugenol varies between $80-90 \%$ in clove bud oil and $82-88 \%$ in clover leaf oil [20]. Cloves are used in Indian ayurvedic medicine, Chinese medicine, and western herbalism and dentistry; where the essential oil is used as an anodyne (painkiller) for dental emergencies. Cloves are used as a carminative, to increase hydrochloric acid in the stomach and to improve peristalsis. Cloves are also said to be a natural anthelmintic [21]. The various basils have similar diverse scents, as the herbs have number of different essential oils that come together in different proportions in variety of breeds. The strong clove scent of sweet basil is derived from eugenol, the same chemical as actual cloves. The flavor of cinnamon is due to eugenol, mostly found in the leaves [22] (Figure 1).

*Corresponding author: RS Bendre, School of Chemical Sciences, North Maharashtra University, Jalgaon, Maharashtra, India, E-mail: bendrers@rediffmail. com

Received March 01, 2016; Accepted March 08, 2016; Published March 15, 2016

Citation: Bendre RS, Rajput JD, Bagul SD, Karandikar PS (2016) Outlooks on Medicinal Properties of Eugenol and its Synthetic Derivatives. Nat Prod Chem Res 4: 212. doi:10.4172/2329-6836.1000212

Copyright: (c) 2016 Bendre RS, et al. This is an open-access article distributed under the terms of the Creative Commons Attribution License, which permits unrestricted use, distribution, and reproduction in any medium, provided the original author and source are credited. 


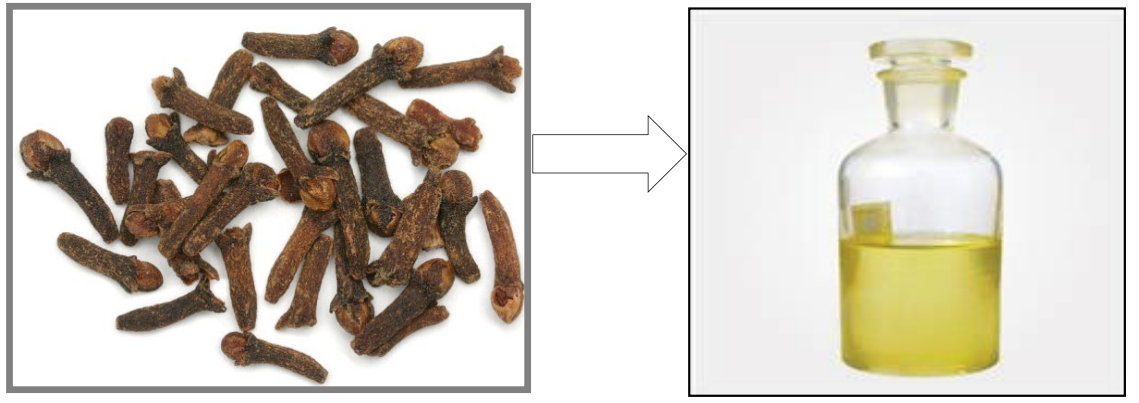

Figure 1: Dried cloves fruits and Eugenol oils.

\section{Isolation of Eugenol}

Eugenol, the principal ingredient in clove oil, is a familiar aroma in many dental offices as it is frequently mixed into a paste and used in medicines [23,24]. It is clear pale yellow oil with a warm, pungent, yet pleasing aroma as the smell of bay leaves and clove. Generally, eugenol is isolated from clove oil; as concentration of eugenol in it is high up to $74.3 \%$ [25]. However, in recent year's isolation of eugenol is achieved from some significant plants, such as Cinnamon, Ocimum tenuiflorum (Tulsi or Holy Basil).

Clove is one of the most important herbs in traditional medicine and its scientific name is Syzygium aromaticum. Commercial eugenol is derived by steam distillation and refinement of oil of clove bud and leaf, cinnamon leaf or basil [26,27]. Cinnamomum zeylanicum is one of the oldest herbal medicines mentioned in Chinese texts 4000 years ago [28]. Wong et al. have reported two methods for extraction of cinnamon's essential oil, to study and identify the active compound of the essential oil and investigate the antimicrobial properties [29]. Holy Basil (Ocimum sanctum) is one of the most widely grown herbs for therapeutic use [30,31]. Hahn and Burkett reported extraction of eugenol from different preparations of Holy Basil [32].

\section{Biologically Active Synthetic Derivatives of Eugenol}

In Recent years, the derivatives synthesized from natural products have been found to possess huge biological activities. Eugenol is interesting naturally occurring phenolic monoterpene belonging to phenylpropanoids group, having versatile actions against bacteria, pathogens and harmful microorganisms. Currently world reputed organizations have taken interests in drug discovery particularly of natural origin.

Carrasco et al. have synthesized and tested in-vitro anticancer activities of eugenol and its nitro and acyl analogues (1-5) against human tumor cells on DU-145 and KB cell lines by MTT assay. Which showed potential human tumor cell growth inhibitory effect [33].

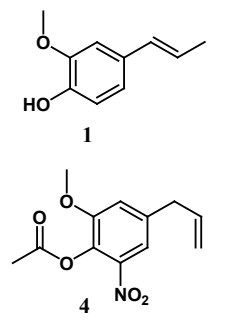<smiles>C=CCc1cc(OC)c(O)c([N+](=O)[O-])c1</smiles><smiles>C=CCc1cc(O)c(O)c([N+](=O)[O-])c1</smiles>
2<smiles>C=CCc1cc(OC)c(OC(C)=O)c([N+](=O)[O-])c1</smiles>

Mikhailovskii et al. have suggested eugenol as a precursor for construction of isoquinoline synthetic alkaloid analogs (6-7) which were prepared earlier by cyclocondensation of nitriles with dialkylbenzylcarbinols via Ritter reaction [34].<smiles>COc1cc2c(cc1O)/C(=C/C(N)=O)NC(C)C2</smiles><smiles>[R]C1NC(C)Cc2cc(OC)c(O)cc21</smiles>

7

Carrasco et al. have synthesized and reported acylated and nitro derivatives of eugenol (8-15) which showed remarkable antifungal activities, with non-targeted assays against a panel of human opportunistic pathogenic fungi. Accompanying studies on the structure-activity relationships are mainly associated to the influence of an allyl substituent at $\mathrm{C}-4$, an $\mathrm{OH}$ group at $\mathrm{C}-1$ and an $\mathrm{OCH}_{3}$ at $\mathrm{C}-2$ or the presence of one or two $\mathrm{NO}_{2}$ groups in different positions of the benzene ring [35].<smiles>C/C=C/c1ccc(O)c(OC)c1</smiles><smiles>C=CCc1cc(OC)c(OC(C)=O)c([N+](=O)[O-])c1</smiles>

11<smiles></smiles>

14<smiles>C/C=C/c1ccc(OC(C)=O)c(OC)c1</smiles><smiles>C=CCc1cc(OC)c(O)c([N+](=O)[O-])c1</smiles>
12<smiles>COc1c(OC(C)=O)cc([N+](=O)[O-])c([N+](=O)[O-])c1CC=[N+]=O</smiles>

15<smiles>C/C=C/c1ccc(OC(C)=O)c(OC)c1[N+](=O)[O-]</smiles><smiles>C=CCc1cc(O)c(O)c([N+](=O)[O-])c1</smiles>

13

Rudyanto et al. have synthesized new 1,3-benzoxazine (16) and amino methyl compounds (17) from eugenol and investigated their brine shrimp lethality test (BST), where it was observed that the derivatives show negative results against BST [36]. Farias et al. has synthesized the distinct series of sixteen ether and ester derivatives of eugenol (18-19) through its structural modifications. Ether derivatives possessing alkyl or aryl groups substituting the hydroxyl group (19) presented promising activities as compared to the esters of eugenol [37]. 


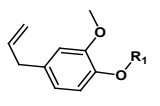

18

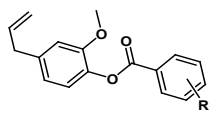

19
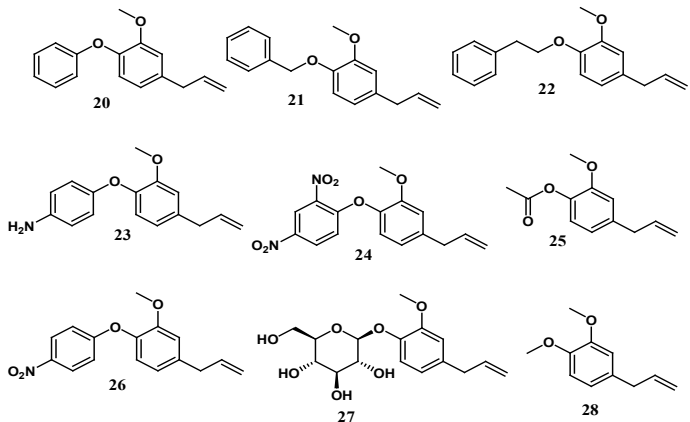

OMe

Dallmeier et al. prepared nine new eugenol derivatives (20-28) and investigated anesthetic, hypothermic, myorelaxant and anticonvulsant effects on rats or mice; in addition to the pharmacological activity which appeared during the experiments. For comparative purposes the study was also extended on six naturally occurring eugenol analogues [38]. Tomasch et al. have design and synthesized novel cinnamic acid derivatives of eugenol containing dimethyl spacer and fluorophore moites (29) which were found to possess strong affinity towards hEP3Rs at nano molar conc. All the derivatives found to inhibit $\mathrm{PGE}_{2}$ and collagen induced platelet aggregation in different extent of series [39]. Fonseca-Berzal et al. have reported particular derivative containing quinoline moieties (30-31) attached to the phenolic oxygen of eugenol and isoeugenol, directly or through a spacer, which was found to be potentially useful as antitrypanosomics against Trypanosoma cruzi in order to generate antiparasitary agents [40].

Chen et al. have derived Eugenol ether derivative (32) and evaluated their protective effects against hydrogen peroxide $\left(\mathrm{H}_{2} \mathrm{O}_{2}\right)$ induced oxidative damage on ECV-304 cells. Eugenol ether (32) has been proved to have a beneficial effect, protecting injured ECV-304 cells with an $\mathrm{EC}_{50}$ value of $0.20 \mu \mathrm{M}$, which comparatively low than standard [41]. Rugulactone, a natural pyrone found in Cryptocaria Rugulosa, which is important factor for inhibition of NK-kB and this factor plays vital role in DNA sequencing [42]. Meragelman et al. have synthesized rugulactone derivative (33) from eugenol using ring closing metathesis<smiles>C=CCc1ccc(OCOc2cccc3cccnc23)c(OC)c1</smiles><smiles>C=CCc1ccc(OCCCCCCOc2cccc3cccnc23)c(OC)c1</smiles><smiles>C=CCc1ccc(OCCOc2cccc3cccnc23)c(OC)c1</smiles>

36

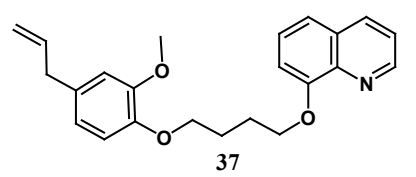

37
Arango et al. have designed and synthesized new eugenol derivatives containing quinoline moiety (34-37) via Williamson approach [43]. reaction of eugenol, alkyl bromide and 8-hydroxyquinaldine. The compounds synthesized were evaluated for antileishmanial activity against $L$. panamensis amastigotes and cytotoxic activity against U-937 cells; where all synthesized derivatives showed notable antileishmanial activity [44].<smiles>COc1ccc(C(=O)/C=C/c2cc(OC)c(OC)c(OC)c2)cc1OC</smiles><smiles>COc1ccc(C(=O)/C=C/c2cc(OC)c(OC)c(OC)c2)cc1OC</smiles><smiles>COc1ccc(C/C=C\c2ccccc2OC(C)=O)cc1OC</smiles><smiles>COc1ccc(/C=C\c2c(C)cccc2C)cc1OC</smiles>

Bar et al. have reported alkylation of the free phenolic group of eugenol and attachment of a substituted aromatic ring to the end of the three-carbon side chain resulting in cytotoxic compounds (38-41)<smiles>[R3]c1ccc(CCC/C=C/c2ccc(OC)c(OC)c2)c([R])c1[R6]</smiles><smiles>[R]c1cccc(C(NCCOc2ccc(CC=C)cc2OC)C(=O)OC)c1</smiles>

A number of substituted cinnamylphenol derivatives (42) containing eugenol moiety have been reported by Ito et al. and tested for inhibitory activities against in vitro Epstein-Barr virus early antigen activation induced by 12-O-tetradecanoylphorbol-13-acetate in Raji cells and results specified that some prenylated cinnamylphenol might be valuable as potential cancer chemo preventive agents [46]. Hernandez et al. have performed etherification on the free phenol of eugenol to construct new series (43) of phenoxyacetic, phenoxyethyl-amido and phenoxyethyl-amido moieties; and evaluated their hipolipidemic activities [47].<smiles>C=CCc1ccc(OCC(=O)N2N=C(c3ccc(Cl)cc3)CC2c2ccc(O)cc2)c(OC)c1</smiles><smiles>[R]Oc1ccc(CC2CC(c3cccc4ccccc34)=NO2)cc1OC</smiles>

45 useful as breast cancer invasion inhibitors [45].

Anewseries of 1,3,5-trisubstituted pyrazolines (44) has been synthesized by Bhat et al. upon condensation of various substituted chalcones with aryloxy acetyl hydrazide derived from eugenol. The synthesized derivatives exhibited significant antibacterial activities compared to gentamycin and moderate antifungal activity in comparison with griseofulvin [48] Maurya et al. prepared a series of novel isoxazolines (45) from 4-allyl-2methoxyphenol derivatives and evaluated their antistress activity in acute stress induced peripheral changes [49].<smiles>[R]c1ccc(SCCCc2ccc(O)c(OC)c2)cc1</smiles><smiles>C=CCc1ccc(OCC(O)CNCCOc2ccccc2OC)c(OC)c1</smiles> 
Sulphur ether derivatives (46) of eugenol were designed via green method by Lenardao et al. All the synthesized compounds were found to have excellent antioxidant activities [50]. Huang et al. prepared innovative derivatives of eugenol (47) and tested them for antioxidant and adrenoceptor antagonistic activities; most of the derivatives exhibited significant $\beta$-adrenoceptor blocking activities [51].

\section{Anticancer Activity of Eugenol}

US Food and Drug Administration (FDA) has declared eugenol to be safe and considered non-carcinogenic and non-mutagenic; and Food and Agriculture Organization (FAO) and World Health Organization (WHO) have specified its permissible uptake limit per day upto $2.5 \mathrm{mg} / \mathrm{kg}$ body weight for humans [52,53]. Eugenol possesses anticancer activity against various types of cancers and reported to have excellent inhibitory effect against number of cancer cell lines [53]. Research of the last several years has demonstrated that the nuclear factor-kappa B (NF- $\mathrm{B}$ ), plays critical role in the regulation of more than 200 genes involved in inflammation, stress response, immune functions, apoptosis, cell proliferation, cell survival, metastasis, and angiogenesis [54,55]. Murakami and Yukio et al. have suggested a probable mechanism for the anti-inflammatory action of bis-eugenol, and suggested it to be potent inhibitor of NF- $\mathrm{KB}$ and useful for the chemoprevention of oral diseases [56]. Ghosh and Rita et al. have screened eugenol and isoeugenol for antiproliferative activity toward melanoma cells. The results suggested that eugenol (4-allyl-2methoxyphenol) has ability to inhibit proliferation of melanoma cells. Eugenol but not its isomer, isoeugenol (2-methoxy-4-propenylphenol), was found to be a potent inhibitor of melanoma cell proliferation [57]. Yoo et al. established the mechanism of anticancer activity of Eugenol for the first time, i.e., eugenol induces apoptosis through Reactive Oxygen Species (ROS) and mitochondria-dependent mechanism, and expressed a possibility to develop it as chemotherapeutic or chemo preventive agent [58]. Manikandan et al. investigated the modulatory effects of eugenol on the expression NF- $\kappa B$ family members ((NF- $\kappa B$, p50 and p65), I $\mathrm{B} \alpha$, phosphorylated I $\kappa \beta \alpha$, pI $\kappa$ - $\alpha$; I $\kappa B$ kinase $\beta$, IKK $\beta$ ) and the NF- $\kappa B$ target genes in a rat model of gastric carcinogenesis and provided evidence that the protective effect of eugenol is due to its ability to inhibit NF- $\mathrm{B}$ activation [59]. Vidhya et al. reported cytotoxic activity of eugenol and its mechanism to induce cell death in human breast cancer cells, where inhibition of the growth was found to be dose and time dependent [60].

\section{Role of Eugenol in Dentistry}

The first type of provisional cement consisting of mixed zincoxide powder and eugenol liquid, creating a paste-like consistency was introduced in 1933. However, the ratio of the powder to liquid varied and caused inconsistent viscosities. Originally added for its sedative property, eugenol liquid provided an obtundent effect to help the pulp "relax" after trauma from tooth preparation [61,62] (Figure 2).

Presently zinc oxide eugenol cement (ZOE) has been widely used in dentistry for indirect pulp capping, and as a temporary filling and root canal sealer [63]. Eugenol is known to be an antioxidant and anti-inflammatory agent. However, eugenol at high concentrations has been reported to have some cytotoxic properties [63]. Guenette
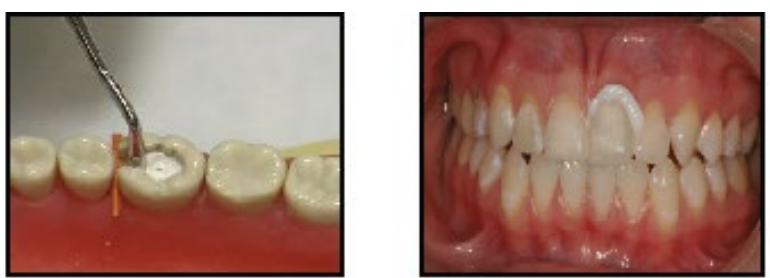

Figure 2: Eugenol Zinc Oxide as Filler in Dentistry. et al. investigated the pharmacokinetics (PK) and anesthetic effects of eugenol with increasing dose levels in male Sprague-Dawley rats [64]. Park et al. have investigated the effects of eugenol on pain behaviors in orofacial area, and as an attempt to explicate its mechanism and characterized inhibitory effects of eugenol on VGSCs in trigeminal ganglion (TG) neurons [65].

\section{Conclusion}

Eugenol is simple phytochemical constituent, exhibiting highly potent anticancer activities that have been attributed to their effects on multiple signaling and apoptotic pathways. The potent medicinal activities of eugenol and its derivatives have in particular, attracted a lot of attention recently. Studies have shown the efficacy of eugenol against a number of different microorganisms of different origin. These findings indicated a possible use of eugenol as therapeutic tool against a wide variety of diseases. The promising numbers on therapeutic potential of phenolic Eugenol is encouraging and further investigations are needed to fully realize the potential of these derivatives in human health and diseases.

\section{Acknowledgements}

We sincerely acknowledge our colleagues and friends for their valuable suggestions and helpful discussions. We would like to thank our present co-worker Dr. Subhash Padhye. We are grateful to UGC and CSIR, New Delhi for funding our research projects at present times.

\section{References}

1. Koeduka T, Fridman E, Gang DR, Vassão DG, Jackson BL, et al. (2006) Eugenol and isoeugenol, characteristic aromatic constituents of spices, are biosynthesized via reduction of a coniferyl alcohol ester. Proceedings of the National Academy of Sciences 103: 10128-10133.

2. Svoboda K, Brooker JD, Zrustova J (2005) Antibacterial and antioxidan properties of essential oils: Their potential applications in the food industries. In I International Symposium on Natural Preservatives in Food Systems 709: $35-44$.

3. Xie Z, Kapteyn J, Gang DR (2008) A systems biology investigation of the MEP/ terpenoid and shikimate/phenylpropanoid pathways points to multiple levels of metabolic control in sweet basil glandular trichomes. The Plant Journal 54 349-361.

4. Sartoratto A, Machado ALM, Delarmelina C, Figueira GM, Duarte MCT, et al (2004) Composition and antimicrobial activity of essential oils from aromatic plants used in Brazil. Brazilian Journal of Microbiology 35: 275-280.

5. Groom N (2012) The perfume handbook. Springer Science \& Business Media

6. Schäfer E, Zandbiglari T (2003) Solubility of root-canal sealers in water and artificial saliva. Int Endod J 36: 660-669.

7. Dorman HJ, Deans SG (2000) Antimicrobial agents from plants: antibacterial activity of plant volatile oils. J Appl Microbiol 88: 308-316.

8. Gurney BF (1965) Patent and Trademark. Washington, DC: U.S. Patent and Trademark Office.

9. Nabi N, Gaffar A, Lucchesi S, Afflitto JJ, Herles SM (1995) Patent and Trademark. Washington, DC: U.S. Patent and Trademark Office.

10. Jadhav BK, Khandelwal KR, Ketkar AR, Pisal SS (2004) Formulation and evaluation of mucoadhesive tablets containing eugenol for the treatment of periodontal diseases. Drug Dev Ind Pharm 30: 195-203.

11. Sarrami N, Pemberton MN, Thornhill MH, Theaker ED (2002) Adverse reactions associated with the use of eugenol in dentistry. British dental journal 193: 253-255.

12. Markowitz K, Moynihan M, Liu M, Kim S (1992) Biologic properties of eugenol and zinc oxide-eugenol. A clinically oriented review. Oral Surg Oral Med Oral Pathol 73: 729-737.

13. Chambers DL, Cunningham RT, Lichty RW, Thrailkill RB (1974) Pest control by attractants: a case study demonstrating economy, specificity, and environmental acceptability. Bioscience 24: 150-152. 
14. Srinivasan K (2005) Spices as influencers of body metabolism: an overview of three decades of research. Food Research International 38: 77-86.

15. Kaefer CM, Milner JA (2008) The role of herbs and spices in cancer prevention. J Nutr Biochem 19: 347-361.

16. Ouk S, Thiébaud S, Borredon E, Le Gars P (2002) Dimethyl carbonate and phenols to alkyl aryl ethers via clean synthesis. Green Chemistry 4: 431-435.

17. Kulkarni MG, Shaikh YB, Borhade AS, Chavhan SW, Dhondge AP, et al. (2013) Greening the Wacker process. Tetrahedron Letters 54: 2293-2295.

18. Kaufman TS (2015) The Multiple Faces of Eugenol. A Versatile Starting Materia and Building Block for Organic and Bio-Organic Synthesis and a Convenient Precursor toward Bio-Based Fine Chemicals. Journal of the Brazilian Chemical Society 26: 1055-1085.

19. Kamatou GP, Vermaak I, Viljoen AM (2012) Eugenol--from the remote Maluku Islands to the international market place: a review of a remarkable and versatile molecule. Molecules 17: 6953-6981.

20. Chicag J Barnes, LA Anderson, JD Phillipson (1996) Herbal Medicines. (3rd edn), CRC Press

21. Alqareer A, Alyahya A, Andersson L (2006) The effect of clove and benzocaine versus placebo as topical anesthetics. J Dent 34: 747-750.

22. Balch JF, Balch PA (1997) Prescription for nutritional healing. Garden City Park NY: Avery Pub Group.

23. Islam MS (2011) Transient receptor potential channels. Springer Science \& Business 704.

24. Douglas WH (1978) The metal oxide/eugenol cements. I. The chelating power of the eugenol type molecule. J Dent Res 57: 800-804.

25. Zheng GQ, Kenney PM, Lam LK (1992) Sesquiterpenes from clove (Eugenia caryophyllata) as potential anticarcinogenic agents. Journal of natural products 55: 999-1003.

26. Barceloux DG (2008) Medical toxicology of natural substances: foods, fungi, medicinal herbs, plants, and venomous animals. John Wiley \& Son.

27. Bedoukian PZ (1986) Perfumery and flavoring synthetics. Allured Pub CorpHealth \& Fitness.

28. Elumalai S, Kesavan R, Ramganesh S, Murugesan R (2011) Isolation, purification and identification of the anti-diabetic components from Cinnamomum zeylanicum and Cinnamomum cassia bark oil extracts. Current Botany 2: 12-17

29. Wong YC, Ahmad-Mudzaqqir MY, Wan-Nurdiyana WA (2014) Extraction of Essential Oil from Cinnamon (Cinnamomum zeylanicum). Oriental Journal of Chemistry 30: 37-47

30. Vani SR, Cheng SF, Chuah $\mathrm{CH}$ (2009) Comparative study of volatile compounds from genus Ocimum. American Journal of Applied Sciences 6: 523-528.

31. Chang X, Alderson PG, Wright CJ (2009) Variation in the Essential Oils in Different Leaves of Basil (Ocimum basilicum L.) at Day Time. The Open Horticulture Journal 2: 13-16.

32. Hahn CN, Burkett JR (2013) Optimizing eugenol extraction conditions from fresh and dried samples of holy basil (Ocimum sanctum). Asian Journal of Plant Science and Research 3: 28-31.

33. Carrasco A, Espinoza C, Cardile V, Gallardo C, Cardona W, et al. (2008) Eugenol and its synthetic analogues inhibit cell growth of human cancer cells (Part I). Journal of the Brazilian Chemical Society 19: 543-548.

34. Mikhailovskii AG, Surikova OV, Limanskii ES, Vakhrin MI (2012) Synthesis of isoquinoline alkaloid derivatives from eugenol. Chemistry of Natural Compounds 48: 1-3.

35. Carrasco H, Raimondi M, Svetaz L, Di Liberto M, Rodriguez MV, et al. (2012) Antifungal activity of eugenol analogues. Influence of different substituents and studies on mechanism of action. Molecules 17: 1002-1024.

36. Rudyanto M, Ekowati J, Widiandani T, Honda T (2014) Synthesis and brine shrimp lethality test of some benzoxazine and aminomethyl derivatives of eugenol. Int J Pharm Pharm Sci 6: 96-98.

37. d' Avila Farias M, Oliveira PS, Dutra FS, Fernandes TJ, de Pereira CM, et al (2014) Eugenol derivatives as potential anti-oxidants: is phenolic hydroxyl necessary to obtain an effect? J Pharm Pharmacol 66: 733-746.

38. Dallmeier K, Carlini EA (1981) Anesthetic, hypothermic, myorelaxant and anticonvulsant effects of synthetic eugenol derivatives and natural analogues. Pharmacology 22: 113-127.

39. Tomasch M, Schwed JS, Kuczka K, Meyer Dos Santos S, Harder S, et al (2012) Fluorescent Human EP3 Receptor Antagonists. ACS Med Chem Lett 3: $774-779$.

40. Fonseca-Berzal C, Ruiz FAR, Escario JA, Kouznetsov VV, Gómez-Barrio A (2014) In vitro phenotypic screening of 7-chloro-4-amino (oxy) quinoline derivatives as putative anti-Trypanosoma cruzi agents. Bioorganic \& medicinal chemistry letters $24: 1209-1213$.

41. Chen H, Li G, Zhan P, Guo X, Ding Q, et al. (2013) Design, synthesis and biological evaluation of novel ligustrazinylated derivatives as potent cardiovascular agents. Med Chem Comm 4: 827-832.

42. Meragelman TL, Scudiero DA, Davis RE, Staudt LM, McCloud TG, et al. (2009) Inhibitors of the NF-kappaB activation pathway from Cryptocarya rugulosa. J Nat Prod 72: 336-339.

43. Cros F, Pelotier B, Piva O (2010) Regioselective Tandem Ring Closing/Cross Metathesis of 1, 5-Hexadien-3-ol Derivatives: Application to the Total Synthesis of Rugulactone. European Journal of Organic Chemistry, pp: 5063-5070.

44. Arango V, Domínguez JJ, Cardona W, Robledo SM, Muñoz DL, et al. (2012) Synthesis and leishmanicidal activity of quinoline-triclosan and quinolineeugenol hybrids. Medicinal Chemistry Research 21: 3445-3454.

45. Bar FMA, Khanfar MA, Elnagar AY, Badria FA, Zaghloul AM, et al. (2010) Design and pharmacophore modeling of biaryl methyl eugenol analogs as breast cancer invasion inhibitors. Bioorganic \& medicinal chemistry 18: 496507

46. Ito C, Itoigawa M, Kanematsu T, Imamura Y, Tokuda H, et al. (2007) Synthetic cinnamylphenol derivatives as cancer chemopreventive agents. European journal of medicinal chemistry 42: 902-909.

47. Hernández D, Bernal P, Cruz A, Garciafigueroa Y, Garduno L, et al. (2004) Potent hypolipidemic activity of mimetic amides of fibrates based on the 2-methoxy-4-(2-propenyl) phenoxyacetic scaffold. Drug development research 61: $19-36$

48. Bhat KI, Hussain MMM (2009) Synthesis, characterization and antimicrobial studies of some substituted pyrazolines from aryloxy acetyl hydrazine. Asian Journal of Chemistry 21: 3371-3375.

49. Maurya R, Ahmad A, Gupta P, Chand K, Kumar M, et al. (2011) Synthesis of novel isoxazolines via 1,3-dipolar cycloaddition and evaluation of anti-stress activity. Medicinal chemistry research 20: 139-145.

50. Lenardao EJ, Jacob RG, Mesquita KD, Lara RG, Webber R, et al. (2013) Glycerol as a promoting and recyclable medium for catalyst-free synthesis of linear thioethers: new antioxidants from eugenol. Green Chemistry Letters and Reviews 6: 269-276.

51. Huang YC, Wu BN, Yeh JL, Chen SJ, Liang JC, et al. (2001) A new aspect of view in synthesizing new type ß-adrenoceptor blockers with ancillary antioxidant activities. Bioorganic \& medicinal chemistry 9: 1739-1746.

52. Opdyke DL (1975) Monographs on fragrance raw materials. Food Cosme Toxicol 13: 449-457.

53. Jaganathan SK, Supriyanto E (2012) Antiproliferative and molecular mechanism of eugenol-induced apoptosis in cancer cells. Molecules 17: 6290-6304.

54. Shen HM, Tergaonkar V (2009) NFkappaB signaling in carcinogenesis and as a potential molecular target for cancer therapy. Apoptosis 14: 348-363.

55. Sethi G, Sung B, Aggarwal BB (2008) Nuclear factor-kappaB activation: from bench to bedside. Exp Biol Med (Maywood) 233: 21-31.

56. Murakami Y, Shoji M, Hanazawa S, Tanaka S, Fujisawa S (2003) Preventive effect of bis-eugenol, a eugenol ortho dimer, on lipopolysaccharide-stimulated nuclear factor kappa B activation and inflammatory cytokine expression in macrophages. Biochemical pharmacology 66: 1061-1066.

57. Ghosh R, Nadiminty N, Fitzpatrick JE, Alworth WL, Slaga TJ, et al. (2005) Eugenol causes melanoma growth suppression through inhibition of E2F1 transcriptional activity. Journal of Biological Chemistry 280: 5812-5819.

58. Yoo CB, Han KT, Cho KS, Ha J, Park HJ, et al. (2005) Eugenol isolated from the essential oil of Eugenia caryophyllata induces a reactive oxygen speciesmediated apoptosis in HL-60 human promyelocytic leukemia cells. Cancer letters 225: 41-52.

59. Manikandan P, Vinothini G, Vidya Priyadarsini R, Prathiba D, Nagini S (2011) 
Eugenol inhibits cell proliferation via NF-kB suppression in a rat model of gastric carcinogenesis induced by MNNG. Invest New Drugs 29: 110-117.

60. Vidhya N, Devaraj SN (2011) Induction of apoptosis by eugenol in human breast cancer cells. Indian J Exp Biol 49: 871-878.

61. Brinker SP (2014) Provisional Excellence with Zinc-Oxide Non-Eugenol Temporary Cement. Provider, 501: 355110.

62. Smith R (2014) Contemporary Products solutions.
63. Gerosa R, Borin M, Menegazzi G, Puttini M, Cavalleri G (1996) In vitro evaluation of the cytotoxicity of pure eugenol. J Endod 22: 532-534.

64. Guenette SA, Beaudry F, Marier JF, Vachon P (2006) Pharmacokinetics and anesthetic activity of eugenol in male Sprague-Dawley rats. Journal of veterinary pharmacology and therapeutics $29: 265-270$.

65. Park CK, Kim K, Jung SJ, Kim MJ, Ahn DK, et al. (2009) Molecular mechanism for local anesthetic action of eugenol in the rat trigeminal system. Pain 144: 84-94. 